mag. Nives

Ličen

Filozofska

fakulteta $v$

Ljubljani

\title{
DEMOKRACIJA 21. STOLETJA SE ZAČENJA V DRUŽINAH
} Kako priti do demokratičnih odnosov in kje
predusem se demokratičnih odnosov učimo?

$\mathrm{N}$

ajbrž je že kar retorični odgovor na to vprašanje, da se medsebojnih odnosov učimo v primarnih skupinah, ki jim človek pripada. Najmočneje se $v$ naše možganske vijuge vtisne učenje $\mathrm{v}$ zgodnjem otroštvu, zato poudarjamo vedno znova družino kot likovno delavnico risanja temeljnih vinjet medsebojnih odnosov, ki se kasneje kot samoumevne prenašajo $\mathrm{v}$ druge medsebojne odnose. $\mathrm{V}$ besedilu govorimo o »demokratičnem kažipotu «, o značilnostih demokratičnih odnosov, kakršne naj bi odrasli in otroci skupaj gradili v svojih družinah.

\section{DEMOKRACIIE SE UČIMO}

Ko govorimo o demokraciji, so naše prve misli prepletene $z$ državnimi institucijami, $s$ parlamentom, s politiko ... Mogoče preplavi naše telo jeza ob misli na "profesionalne demokracije« evropskih držav, ko si »poklicni« po-

Za demokracijo je potrebna moralna in duhovna vzgoja slanci izbirajo volilna okrožja in ne obratno, da bi lokalna pobuda izbirala poslance. Kakor koli že, demokracije ne sestavljajo samo pravne institucije. Demokracija je v mnogočem stvar senzibilnosti, zato ne deluje, pa četudi je še tako zapovedana ali propagirana, če ljudje niso občutljivi drug za drugega.

Demokracija temelji na določeni kulturi, ki jo človek pridobiva počasi, z učenjem. Valadier meni, da je kultura, na kateri sloni demokracija, sestavljena iz moralnih in političnih vrlin. Demokratična kultura postavlja svobodo pred pasivni konformizem, odgovornost, inventivnost in delo pred opuščanje nalog in zanemarjanje le-teh, spoštovanje mišljenja drugih in pluralizem pred slepo poslušnost in preziranje nasprotnikov. Demokracija sloni na moralni in duhovni vzgoji, brez te je le prazna lupina. (Valadier 1991, po Mougniotte 1995.)

V nekaterih deželah, kot npr. na Danskem, lahko občutimo, da ni le prazna lupina. Posamezniku puščajo dovolj prostora. Neodvisnost posameznika jim je pomembnejša kot moč, ki jo dobijo z disciplino skupnosti. Kot lahko beremo v sagah, so se danski junaki v davni preteklosti umaknili na Islandijo, ker se niso hoteli ukloniti jarmu norveških kraljev. Neznosno jim je bilo, da je kralj od njih lahko zahteval, naj se udeležijo vojnega pohoda, ko se je vojskoval kralj in ne oni sami. Sporočila o svobodoljubnosti in pomembnosti posameznika se $\mathrm{v}$ pripovedih $\mathrm{z}$ izrazito pesniško močjo prenašajo že stoletja na mlajše generacije. Pomembna sporočila se prenašajo iz generacije v generacijo znotraj družin in drugih skupnosti. Dandanes velikokrat slišimo, da je za vse kriva družina, da sta kriza in razsulo družine povzročila naraščanje negativnih pojavov korupcije, mamil ... Kriminalne zablode ne moremo pripisati le družini in jo okriviti za vse blato današnjega sveta. Prav tako tudi ne moremo trditi, da je družina edina, ki nudi "sociološka zdravila «. Je pa prav gotovo pomembna, in sicer $\mathrm{z}$ vidika socializacije otrok in tudi socializacije odraslih.

\section{SESTAVINE UČENIA ZA DEMOKRATIČNE ODNOSE}

$\mathrm{Na}$ vzgojo in izobraževanje za demokracijo gledamo s treh vidikov. Prvi je izkustveno učenje, drugi je razvijanje vrednot in tretji je izobraževanje kot spoznavanje podatkov, problemov in odločanje v zvezi z njimi. (Mougniotte 1995.)

Demokratičnega vedenja se ni mogoče učiti le po spoznavni poti, temveč je pomembna tudi 
čustvena in doživljajska raven, ker gre za vrednote, stališča, slog življenja. Poglaviten del izkustvenega učenja $\mathrm{v}$ zvezi $\mathrm{z}$ demokracijo poteka v družini. Učitelji so starši, bratje in sestre pa tudi otroci svojim staršem. Demokratična kultura ni toliko odvisna od tega, kaj slišimo v govorih javno nastopajočih, temveč je bolj odvisna od tega, kaj ljudje doživljajo v zanje čustveno pomembnih skupinah. Psihiatri s področja transakcijske analize, kot sta Eric Berne in Thomas Harris, trdijo, da so čustva, ki jih človek doživlja v prvih petih letih življenja, v njem najmočnejša tudi v nadaljnjem življenju. Za "prepisovanje» osnovnih zapisov v človekovem možganskem računalniku potrebuje posameznik veliko energije, volje in tudi pomoči. Če so že osnovni zapisi naklonjeni demokratični kulturi, jih je potrebno le razvijati, v nasprotnem primeru se mora odrasli tega šele učiti.

Vsem nam je v korist spodbujanje družinskega okolja, v katerem se starši in otroci medsebojno spoštujejo, tako da se upošteva pravica drugih članov družine v korist celotnega družinskega sistema.

Znati moramo ustvarjati družine, $v$ katerih starši učijo otroke spoštovati avtoriteto, vendar ne podrejanja; družine, $v$ katerih premoč staršev $\mathrm{v}$ znanju ne potisne radovednosti otroka in njegovega zaupanja $v$ lastne sposobnosti za premagovanje težav. Demokratična družina ne pomeni, da se pri odločitvah glasuje ali da je $v$ njej brezpogojno vse dopuščeno, temveč da obstaja odgovornost družinskih članov. Demokratični odnosi so povezani z zaupanjem in odgovornostjo.

Družinsko življenje je dandanes bolj zapleteno kot v preteklosti, ker ni utečenih vzorcev, ki bi se dolgotrajno prenašali iz generacije $\mathrm{v}$ generacijo, oziroma so vzorci, ki jih starši prinašajo iz svojega včerajšnjega otroštva, zastareli za današnji dan. Vsaka družina gradi svoje vzorce reševanja konfliktov, medsebojnega sporazumevanja, odločanja. Demokracija pomeni skupno odločanje. To pa vključuje osebno odgovornost. Medsebojna odvisnost terja vzajemno odgovornost. Ni nujno, da se vedno posameznik prilagaja. Nasprotno: demokratično vedenje predpostavlja aktivno poseganje $\mathrm{v}$ medsebojne odnose in organiziranje medsebojnih odnosov. Odgovornost in spoštovanje drugega ni izgovor za nedejavnost, za indiferentnost. Odgovornost pomeni predvidevanje, uvid $\mathrm{v}$ posledice delovanja ali nedelovanja, pomeni uvid $\mathrm{v}$ to, kar povzročamo ali bi lahko povzročili in smo za to odgovorni pred neko avtoriteto, še posebej pred avtoriteto lastne vesti. Vzgajati v družini pomeni tudi vzgajati občutek odgovornosti pri otrocih in pri odraslih članih družine.

Tretja sestavina učenja za demokracijo je spoznavanje podatkov in odločanje $\mathrm{v}$ zvezi $\mathrm{z}$ njimi. V sodobnem svetu je na voljo vsakodnevno ogromno informacij. Nekateri raziskovalci medijev govorijo o kulturološkem aidsu. Čim hitreje informacije prihajajo, tem hitreje jih mora posameznik rekombinirati, se $\mathrm{v}$ zvezi $\mathrm{z}$ njimi odločati in ustvarjati nove koncepte. $\mathrm{Za}$ starše prinaša pospešeno ustvarjanje novega sveta večjo odgovornost. Stari vzorci mišljenja in pasivno prilagajanje ne zadostujejo več. Mogoče bi to bilo dovolj za plavanje s tokom, ni pa dovolj, da bi sami sebe upravljali na grebenu informacijskega vala postindustijske družbe. Starši potrebujejo take spretnosti mišljenja, ki jim omogočajo informacije izbirati in prilagajati za vsakodnevno družinsko uporabo, informacije morajo nenehno ustvarjalno prilagajati svojemu življenju, svojim otrokom in svojemu mikrookolju. Ustvarjalno prilagajanje sloni na mišljenju, ki je osebno, intuitivno in hkrati logično, zahteva kreativne miselne procese, kajti potrebno je vedno znova prilagajati svoje paradigme. Paradigma je mišljena kot vrsta pravil, ki jih uporabljamo, ko informacije vrednotimo in jih vključujemo $\mathrm{v}$ svoje družinsko življenje. Na življenjskih izkušnjah

V vsakdanjem življenju pa opažamo, da velike komunikacijske možnosti ne vodijo tudi $\mathrm{v}$ uspešno sporazumevanje, $\mathrm{v}$ demokratične odnose. Ustvarjalno se moramo lotiti medsebojnih odnesov, če želimo demokracijo tudi uresničevati, ne le o njei govoriti.

staršev temeljijo njihove osebne paradigme. Te paradigme so jim v mnogočem koristne, lahko pa jih tudi omejujejo. Lahko jim prikrivajo priložnost, ker njihov referenčni okvir ne potrdi obstoja priložnosti (prim. de Bono 1994).
As $3-40$ 
$\mathrm{V}$ informacijski dobi postaja svet majhen. Prostorska oddaljenost ni več ovira. Ljudje smo si vedno bližji. Sprašujemo se, kako smo si bližji in $\mathrm{s}$ kom. S sosedom $\mathrm{v}$ virtualnem prostoru na internetu ali s sosedom $\mathrm{v}$ domačem bloku.

\section{„DEMOKRATIČNI KAŽIPOT« IZPISUIEMO V DRUŽINI}

Temeljne značilnosti demokratične kulture so:

- tolerantnost in spoštovanje pravic drugega,

- sodelovanje,

- odgovornost,

- sporazumevanje.

$\mathrm{Na}$ znaku, ki ga imenujemo »demokratični kažipot «, je izpisano: dialog, odgovornost do sebe in do drugega.

Družinska skupnost s svojim načinom življe-

Dialoga se naučimo ali pa ne naučimo $v$ družini. žịnska vzgoja v rosnih letih in življenje odraslega v demokratičnih odnosih družinske skupnosti. Lastnosti, ki jih goji demokratična družina, so: zaupanje v soljudi, občutek avtonomnosti, pozitivna samopodoba. Če želijo starši prenašati takšne poteze na generacije, ki prihajajo, je nujno razmisliti o dogajanjih $\mathrm{v}$ sodobnih družinah. Če želimo ustvarjati nov svet za otroke, moramo najprej ustvariti svet v sebi. Odrasli člani družine potrebujejo izobraževanje za demokracijo, da bodo le-to gradili v svojih družinah.

\section{KAKO SE UČIMO DEMOKRACIJE V DRUŽINI}

Učenje za demokratične odnose zajema tudi učenje reševanja konfliktov. V času, ko vladajo odnosi »dobim - izgubiš «, pogosto tudi v družinah velja načelo, da odrasli dobijo, otroci izgubijo ali obratno. Tisti, ki izgubi, se vedno počuti prikrajšanega. Odrasli je navadno v družini avtoriteta, zato ima pomembno nalogo v učenju odnosov "dobim - dobiš «. Uresničevanje te naloge ne poteka tako, da dovoli otrokom početi vse, kar sami hočejo; in tudi ne tako, da vse opravi namesto otrok. V stoletju otroka je pogosto napačno razumljeno geslo »Vse za otroka ", in sicer tako, da odrasli vse naredijo za otroka, tako da otroku nič ne preostane, kot je zapisal Trstenjak (Trstenjak 1994). Če smo strpni, zapuščamo geslo, da mora eden biti poražen, drugi pa zmagovalec. S sočlovekom imamo možnost skupnega bivanja brez poražencev. Družina je

Naloga odraslega je, da porazdeli moć med seboj in otroki, da porazdeli odgovornost, da $\mathrm{z}$ otroki skupaj deluje $\mathrm{v}$ različnosti posameznih članov družine. Toleranca se začne s sprejemanjem drugega človeka kot človeka Z vsemi njegovimi potrebami in različnostmi.

osnovna celica takšnih odnosov. Tu člani zorijo $\mathrm{v}$ partnerski ljubezni in $\mathrm{v}$ ljubezni med starši in otroki. Obe generacijski podskupini $v$ družini: otroci in starši, se brusita $v$ toleranci, če gradita svoje odnose na medsebojnem sprejemanju in spoštovanju, če si puščata prostor, ki ga vsak potrebuje. Pustiti prostor drug drugemu pomeni, da se zavedamo meja in ekvivalentnosti partnerjev ter komplemenjem delu Childhood and Society, je za demokracijo neke družbe izjemnega pomena dru- 
tarnosti posameznikov. Medsebojnih odnosov, kjer velja »dobim - dobiš «, se učimo, zato je priložnost, da se starši naučijo skupaj z otroki tistega, česar mogoče niso znali ob vstopu v zakon. Družinsko življenje z močnim čustvenim nabojem daje možnosti za to. Vzgoja otrok ni le odgovorna naloga, je tudi možnost za lasten osebnostni razvoj.

Za demokratične odnose je značilna odprtost za druge ljudi, ki sloni na tem, da:

- drugim prisluhnemo,

- se učimo sprejemati sebe in druge,

- se učimo pozitivne naravnanosti do sveta.

\section{Prisluhnimo, da bomo izvedeli, ali učenje komunikacije}

Učimo se z opazovanjem drugih in sebe, $\mathrm{z}$ zavedanjem lastnega obnašanja. Da zaznamo sebe $\mathrm{v}$ socialnem kontekstu, potrebujemo znanje. Od otroštva dalje se učimo sporazumevati o različnih interesih. Otroke vzgajamo za življenje $\mathrm{v}$ skupnosti in v miru. $\mathrm{V}$ družini obstajajo različna mnenja, interesi. Znati moramo o tem govoriti in poslušati, sprejemati mnenje drugega, ki je različno od našega. Če mižimo ob konfliktih, to vodi v razmere, da so pravice šibkejšega vedno poražene. Obvladati moramo pogajalske veščine, da iščemo rešitve, ki ustrezajo obema stranema. Pogovarjanje zajema govorjenje in poslušanje, kajti pogovor ima dve smeri, zato se učimo govoriti, poslušati in tudi molčati. Včasih je potreben molk, da sporočimo pomembne stvari, ki bi jim besede obrusile izrazitost.

Kdor misli, da ima vedno prav, se ne zna pogovarjati, on zna le govoriti poslušalcem, zna le »pridigati « otrokom ali pa partnerju. Če se želimo pogovarjati, moramo dopuščati možnost, da ima tudi sogovornik svoj prav.

\section{Odločitve posameznika zadevajo tudi druge ljudi ali učenje odgovornosti}

Odnosa do drugih se učimo z osvajanjem veščin odločanja in s sprejemanjem odgovornosti za svoje odločitve, ki zadevajo druge ljudi. Zavedati se moramo, da se učimo tudi iz napačnih odločitev. Vsi družinski člani naj imajo možnost izbire. Tudi otrok lahko izbira v mejah svoje sposobnosti odločanja, kajti le

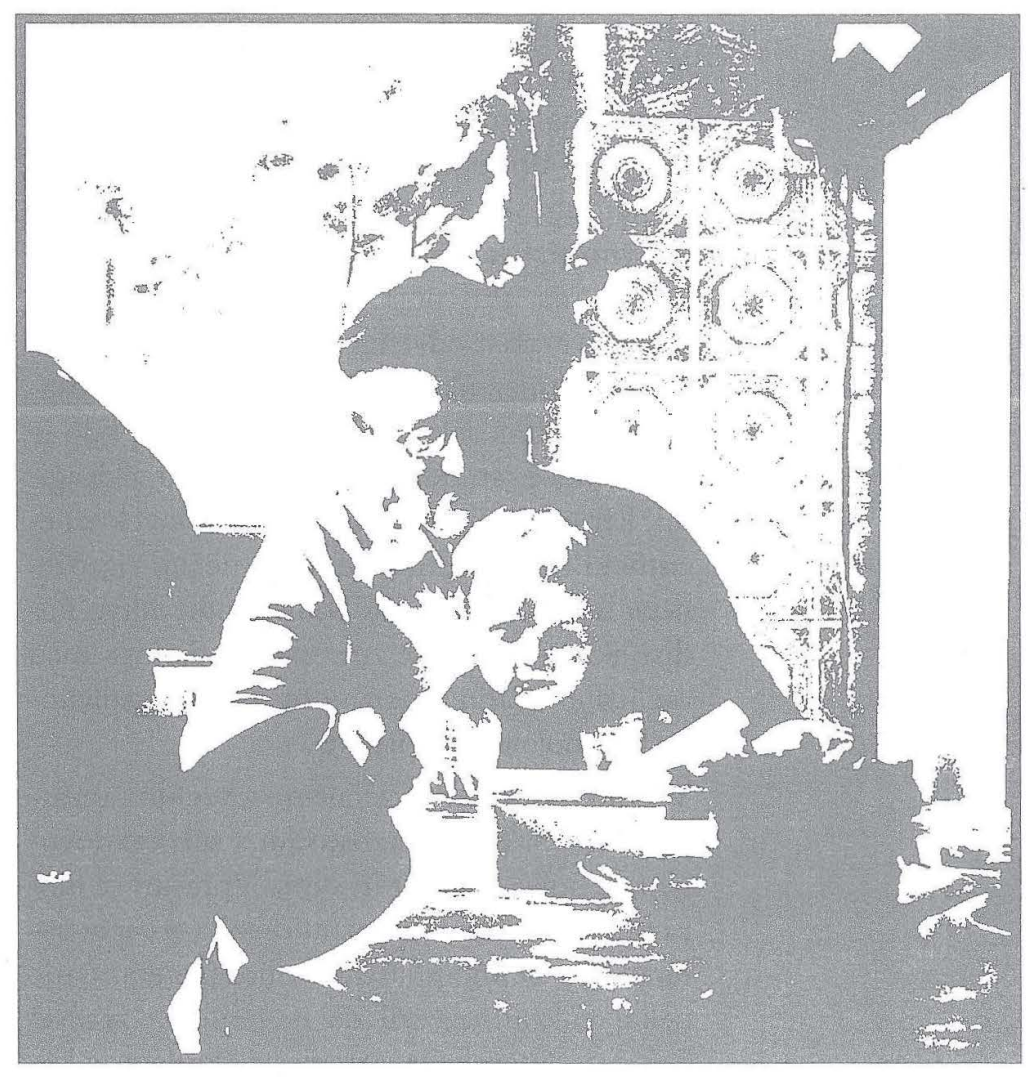

tako se bo odločanja naučil. Odločanje se nanaša tudi na načine obnašanja, ki jih izbiramo. V družinskih medsebojnih odnosih si morajo člani puščati dovolj prostora in časa, v katerem se odločajo in izbirajo ter so odgovorni za posledice svojih izbir.

\section{Pozitivna samopodoba ali učenje pozitivne naravnanosti do sebe in do sveta}

Najbolj zdravi so tisti odnosi, ki rastejo iz optimizma. Optimizem in pesimizem kot človekovi naravnanosti pri gledanju na svet ilustrira primera s kozarcem, ki je do polovice napolnjen z vodo. Optimist pravi, da je kozarec do polovice poln, pesimist pa, da je kozarec na pol prazen. Isti pojav vidita različno. Optimist vidi v sebi in $\mathrm{v}$ svetu svetle strani, pesimist pa temne. Če pa so svetle, jih pesimist vedno pospremi z »ampak«. Ti dve naravnanosti pomembno posegata $\mathrm{v}$ medsebojne odnose in

Samopodoba
družinskih članov
pomembno vpliva na
demokratične odnose
$v$ družini.
moč pozitivnega mišljenja je znana, zato je pomembno $z$ vzgojo in izobraževanjem popravljati črnogledost. Otrok dobi temeljni odnos do sebe in do sveta ob starših. Pomem- 
bno je, kako o svetu razmišljajo starši. Če v družini velja, da je svet grd in ogrožujoč, se otrok $\mathrm{v}$ takem svetu počuti majhnega in ranljivega. Taka podoba o sebi se mu še utrjuje, če ne dobi nobene spodbude od domačih za aktivnosti, s katerimi bi izkusil, da je pomembna lastna aktivnost za doseganje uspehov, da je stvarnost odvisna tudi od ravnanja vsakega posameznika, tudi od njega. Ko je posameznik sam s sabo zadovoljen, ko ve, kdo je in kaj hoče, se odprto sporazumeva $\mathrm{z}$ drugimi, ker ga različnosti ne motijo. Človek z negativno samopodobo se hitro počuti ogroženega in zato se obnaša bodisi podredljivo bodisi ukazovalno. Ne zna speljati dialoga med različnimi ljudmi, ne zmore sprejeti različnosti kot možnosti za učenje.

Vzgojo za toleranco začnemo z vzgojo samospoštovanja. Ko je človek sam s sabo zadovoljen, je boljši partner in starš. Vprašati se moramo, kaj učimo v družini otroka o njem samem. Ga učimo z lastnim obnašanjem, da je nekaj enkratnega ali da je popolna zguba? Zgodnje interakcije s starši in okoljem, v katerem živi, so temelj, na katerem sloni nadaljnji osebnostni razvoj. Samospoštovanje ne vodi $v$ sebičnost, ampak $v$ upoštevanje drugega in sebe.

\section{ZAKLJUČEKK}

V želji po ustvarjanju družbe, ki bo temeljila na človekovih pravicah, ki bo strpna do različnosti, začenjamo pri družinah, kjer se ustvarjajo psihološki pogoji za demokratične odnose. Vsak posameznik z razvitimi moralnimi normami in vrednotami gradi demokracijo sveta, za katero smo vsi odgovorni. Dejstvo je, da živimo skupaj posamezniki in sku-

Učenje socialnih odnosov se začne $v$ družini, zato potrebuje prav družina vso podporo in izobrazbo, da se bodo $v$ njej razvijali strpni ljudje. V družini se namreč učimo komuniciranja, odgovornosti in tolerance, učimo se vseh temeljnih postavk za demokratično kulturo. pine $\mathrm{z}$ različnimi vrednotami, da se srečujemo bolj in manj odprti ljudje. Znanje pri tem pomaga, saj gre za priučene vedenjske lastnosti. Vedno več je vrstniškega nasilja, poleg droge in alkohola ogroža mlade čuden očiščevalski duh, na cestah ne marajo tujcev, $v$ šolah ne prenašajo drugačnosti. Ne vedno in povsod, vendar dovolj pogosto, da smo ob tem zamišljeni in se vprašamo, kaj lahko naredimo, da bo različnost sprejeta kot kvaliteta, kot pestrost življenjskega prostora in ne kot ogrožajoč dejavnik.

Ugotavljamo, da ni zgolj naključje, od koga kot odrasli sprejemamo vplive. Otrok, katerega vzgojna pot se je vila v nasilju, začuti v odraslosti prav v diktaturah bližino družinske reference. Družinska vzgoja je izjemnega pomena za bodoči svet. Od družinske vzgoje je v veliki meri odvisno, ali bo človek od svobode bežal ali jo bo znal sprejeti, s tem pa sprejeti odločanje, sprejeti različnost drugih od sebe in odgovornost za lastno življenje in za razvoj svojega okolja.

Potrebujemo načrtno pripravo za demokratične odnose. Podobno kot država skrbi za promocijo učinkovite rabe energije bi mogoče morali podpreti tudi promocijo vzgoje in izobraževanja odraslih za medsebojne demokratične odnose, kakršne naj omogočajo že starši svojim otrokom.

\section{LITERATURA}

Bollea, G. (1995): Le madri non sbagliano mai. Milano: Feltrinelli.

Bronfenbrenner, U. (1979): The ecology of human development. Cambridge: Harvard University Press.

De Bono, E. (1994): Parallel Thinking. London: Viking.

Dolto, F. (1995): I problemi dei bambini. Milano: Mondadori.

Johnson, W. D. (1986): Reaching out: Interpersonal effectiveness and self-actualization. Englewood Cliffs: Prentice Hall.

Krajnc, A. (1995): Kje se lahko učimo demokracije?, Andragoška spoznanja, I., št. 1-2, str. 5-9.

L Abate, L. \& Milan, M. A. (ur.) (1985): Handbook of social skills training and research. New York: John Wiley \& sons.

Lidz, T. (1971): Familie und psychosoziale Entwicklung. Frankfurt am Main: Fischer.

Miller, A. (1990): The Untouched Key. New York Doubleday.

Mougniotte, A. (1995): Odgajati za demokraciju. Zagreb: Educa.

Svetina, M. (ur.) (1995): Vloga izobraževanja odraslih pri demokratizaciji družbe. Ljubljana: Andragoško društvo Slovenije.

Schlenker, B. R. (ur.) (1985): The Self and Social Life. New York: McGraw-Hill Book Company.

Trstenjak, A. (1994): O družini. Ljubljana: Inštitut Antona Trstenjaka.

Winkel, R. (ur.) (1995): Djeca koju je teško odgajati. Zagreb: Educa. 